\title{
Polar Bear Aerial Survey in the Eastern Chukchi Sea: A Pilot Study
}

\author{
THOMAS J. EVANS, ${ }^{1,2}$ ANTHONY FISCHBACH, ${ }^{3}$ SCOTT SCHLIEBE, ${ }^{1}$ BRYAN MANLY, ${ }^{4}$ \\ SUSANNE KALXDORFF ${ }^{1}$ and GEOFF YORK ${ }^{3}$
}

\author{
(Received 23 August 2002; accepted in revised form 25 March 2003)
}

\begin{abstract}
Alaska has two polar bear populations: the Southern Beaufort Sea population, shared with Canada, and the Chukchi/ Bering Seas population, shared with Russia. Currently a reliable population estimate for the Chukchi/Bering Seas population does not exist. Land-based aerial and mark-recapture population surveys may not be possible in the Chukchi Sea because variable ice conditions, the limited range of helicopters, extremely large polar bear home ranges, and severe weather conditions may limit access to remote areas. Thus line-transect aerial surveys from icebreakers may be the best available tool to monitor this polar bear stock. In August 2000, a line-transect survey was conducted in the eastern Chukchi Sea and western Beaufort Sea from helicopters based on a U.S. Coast Guard icebreaker under the "Ship of Opportunity" program. The objectives of this pilot study were to estimate polar bear density in the eastern Chukchi and western Beaufort Seas and to assess the logistical feasibility of using shipbased aerial surveys to develop polar bear population estimates. Twenty-nine polar bears in 25 groups were sighted on 94 transects $(8257 \mathrm{~km})$. The density of bears was estimated as 1 bear per $147 \mathrm{~km}^{2}(\mathrm{CV}=38 \%)$. Additional aerial surveys in late fall, using dedicated icebreakers, would be required to achieve the number of sightings, survey effort, coverage, and precision needed for more effective monitoring of population trends in the Chukchi Sea.
\end{abstract}

Key words: aerial survey, Ursus maritimus, polar bear, Beaufort Sea, Chukchi Sea, line transect, icebreaker

RÉSUMÉ. L'Alaska a deux populations d'ours polaires: celle du sud de la mer de Beaufort, commune avec le Canada, et celle de la mer des Tchouktches / mer de Béring, commune avec la Russie. À l'heure actuelle, on ne possède pas d'estimation fiable de la population de la mer des Tchouktches / mer de Béring. En raison des conditions variables de la glace, de la portée limitée des hélicoptères, de la très grande étendue du domaine vital de l'ours polaire et des conditions météorologiques particulièrement mauvaises - facteurs qui limitent l'accès aux régions éloignées -, il n'est peut-être pas possible d'effectuer des relevés aériens à base terrestre de la population ou des relevés par marquage-recapture. Le meilleur outil disponible pour une surveillance continue de cette population d'ours polaires semble donc être le relevé de transects effectué depuis les airs par un appareil embarqué sur un brise-glace. En août 2000, un relevé de transect a été effectué dans l'est de la mer des Tchouktches et dans l'ouest de la mer de Beaufort depuis des hélicoptères embarqués sur un brise-glace de la garde côtière américaine sous les auspices du programme des navires de passage. Les objectifs de cette étude pilote étaient d'estimer la densité de l'ours polaire dans l'est de la mer des Tchouktches et l'ouest de la mer de Beaufort, et d'évaluer la faisabilité logistique de l'utilisation d'hélicoptères embarqués pour établir des estimations de la population d'ours polaires. Vingt-neuf ours polaires répartis en 25 groupes ont été aperçus dans 94 transects $(8257 \mathrm{~km})$. La densité des ours était évaluée à 1 animal par $147 \mathrm{~km}^{2}(\mathrm{CV}=38 \%)$. Il faudrait réaliser d'autres relevés aériens à la fin de l' automne, en ayant recours à des brise-glace spécialisés, pour en arriver au nombre d'observations, aux activités de relevés, à la couverture et à la précision nécessaires à une surveillance plus efficace des tendances démographiques dans la mer des Tchouktches.

Mots clés: relevé aérien, Ursus maritimus, ours polaire, mer de Beaufort, mer des Tchouktches, mer de Béring, transect, briseglace

Traduit pour la revue Arctic par Nésida Loyer.

\section{INTRODUCTION}

The Chukchi/Bering Seas polar bear (Ursus maritimus) population is jointly managed by the United States and the Russian Federation (Lunn et al., 2002). In the United States, the Fish and Wildlife Service (USFWS) is responsible under provisions of the Marine Mammal Protection
Act of 1972 (MMPA) to manage polar bear populations within the optimum sustainable population level. Under the MMPA, only Alaska Natives are allowed to hunt polar bears for subsistence needs and for making handicrafts; they currently harvest 60 to 100 bears annually from the Chukchi/Bering Seas polar bear population (Lunn et al., 2002). Russia prohibited polar bear hunting in 1956 in

\footnotetext{
${ }^{1}$ U.S. Fish and Wildlife Service, Marine Mammals Management, 1011 E. Tudor Road, Anchorage, Alaska 99503, U.S.A.

${ }^{2}$ Corresponding author: Thomas_Evans@fws.gov

${ }^{3}$ U.S. Fish and Wildlife Service, Kodiak National Wildlife Refuge, 1390 Buskin Road, Kodiak, Alaska 99615, U.S.A.

${ }^{4}$ Western Ecosystems Technology Inc., 2003 Central Ave, Cheyenne, Wyoming 82001, U.S.A.

(C) The Arctic Institute of North America
} 
response to population declines caused by overharvest; however, in recent years, an increase in illegal harvest from the Chukchi/Bering Seas stock has been noted (Nikita Ovsyanikov, pers. comm. 2002, 2003). On 16 October 2000, the United States and the Russian Federation signed the Agreement on the Conservation and Management of the Alaska-Chukotka Polar Bear Population (Lunn et al., 2002). The Agreement supports polar bear hunting for subsistence purposes by both Alaskan and Russian Natives, and it provides a framework for the future management, enforcement, and allocation of harvest between the two countries. This agreement requires accurate population data to determine sustainable harvest levels. Although population estimates are available for the Southern Beaufort Sea population of northern Alaska ( $n=2272$, USFWS, 2002b), population data are limited for the Chukchi/Bering Seas population of western Alaska (McDonald et al., 1999; USFWS, 2002a). In August 2000, we conducted an aerial survey to estimate polar bear density in the eastern Chukchi and western Beaufort Seas and to assess the logistical feasibility of using ship-based aerial surveys for this purpose.

\section{METHODS}

\section{Study Area}

The aerial survey was conducted in the eastern Chukchi Sea and western Beaufort Sea between $70^{\circ}$ and $75^{\circ} 30^{\prime} \mathrm{N}$ latitude and $168^{\circ}$ and $146^{\circ} \mathrm{W}$ longitude (Fig. 1). Amstrup et al. (2001) identified a new polar bear activity area, referred to as the eastern Chukchi Sea, by analyzing 335 locations of 36 satellite radio-tagged polar bears in the eastern Chukchi and western Beaufort Seas from 1984 through 1998. The eastern Chukchi Sea polar bear group occurs in the area of overlap between the Southern Beaufort Sea and the Chukchi/Bering Seas populations (Amstrup et al., 2001; USFWS, 2002a, b). We focused our survey efforts in the area bounded by the 80th-percentile activity contour of polar bears in the eastern Chukchi Sea for July through September (Fig. 1).

\section{Survey Design}

Aerial surveys were conducted from the U.S. Coast Guard (USCG) icebreaker Polar Star under the "Ship of Opportunity" program. This program supports scientific investigations at a reduced cost, with the understanding that the ship's course and activity are controlled by the USCG and that the scientific studies are secondary to the ship's primary mission. The ship's officers worked to maximize the opportunities to fulfill the objectives of as many studies as possible. We flew line-transect surveys from the USCG icebreaker using two USCG HH-65A helicopters (Aerospatiale Dauphine AS 365N2). The helicopters had fuel for approximately two flight hours and a range of $100-185 \mathrm{~km}$ from the ship.
The ship track started in the western part of the study area and moved east within the pack ice. If possible, the captain avoided areas that contained heavy ice; therefore, the ship was not randomly located with respect to the ice conditions. Planning meetings predetermined the approximate ship location for the next day. We attempted to offset the location of the ship at least $55 \mathrm{~km}$ from the previous survey day's location to allow greater coverage of the study area. Before the survey, we created a grid of northsouth survey lines spaced $1 \mathrm{~km}$ apart. The starting point for each transect was randomly selected each day from the 10 transects closest to the ship's position. Typically, eight transects ( 2 aircraft $\times 2$ transects $\times 2$ sorties), located $10 \mathrm{~km}$ apart and approximately $100 \mathrm{~km}$ long, were flown each day, the first sortie between 0800 and 1000 hours, and the second between 1400 and 1600 hours. Flight times were chosen to accommodate the ship's daily schedule and the needs of the ship's primary mission. If poor visibility was encountered, we discontinued the survey. Flights during poor survey conditions were excluded from survey effort and analysis. Surveys were flown at a target altitude of

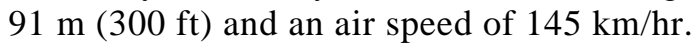

The aircraft flight crew included two pilots, a member of the aviation crew who served as a data recorder, and two primary observers, one on each side of the aircraft. The primary observers rotated between the left and right sides of the aircraft daily. Pilots were instructed not to announce a polar bear sighting until after the observers had had a chance to see it. Polar bears seen by the pilots, but not initially seen by the primary observers, were not included in the analysis. Observers concentrated on detecting polar bears, ringed seals (Phoca hispida), bearded seals (Erignathus barbatus), and Pacific walrus (Odobenus rosmarus divergens) within $0.5 \mathrm{~km}$ of the aircraft, although bears were observed at distances up to $1 \mathrm{~km}$. Observers placed their heads in a standard position and marked the initial sighting of each polar bear group on the aircraft window. After the flight, this mark was used to determine the angle to the sighting with an inclinometer (Suunto, Vantaa, Finland). After each polar bear sighting, the helicopter circled back to confirm the group size and then resumed the survey at the location of the initial sighting. Observers noted changes in flight mode, altitude, weather, and ice conditions and classified the sighting conditions as good, fair, or poor visibility. Observers estimated the percentage of sea ice coverage within the survey strip to the nearest $10 \%$ and classified sea ice stage of development and form as defined by Smith (2000).

The data recorder entered observations on data forms and noted the time of each observation to the nearest second, using a watch synchronized with the GPS. A Garmin GPS III+ (Olathe, Kansas) recorded the aircraft position every 15 seconds. After each flight, the GPS track $\log$ was downloaded into Microsoft Access 2000. The aircraft position at the time of each observation was interpolated from the GPS track log. The perpendicular distance of each sighting from the inside edge of the observable 


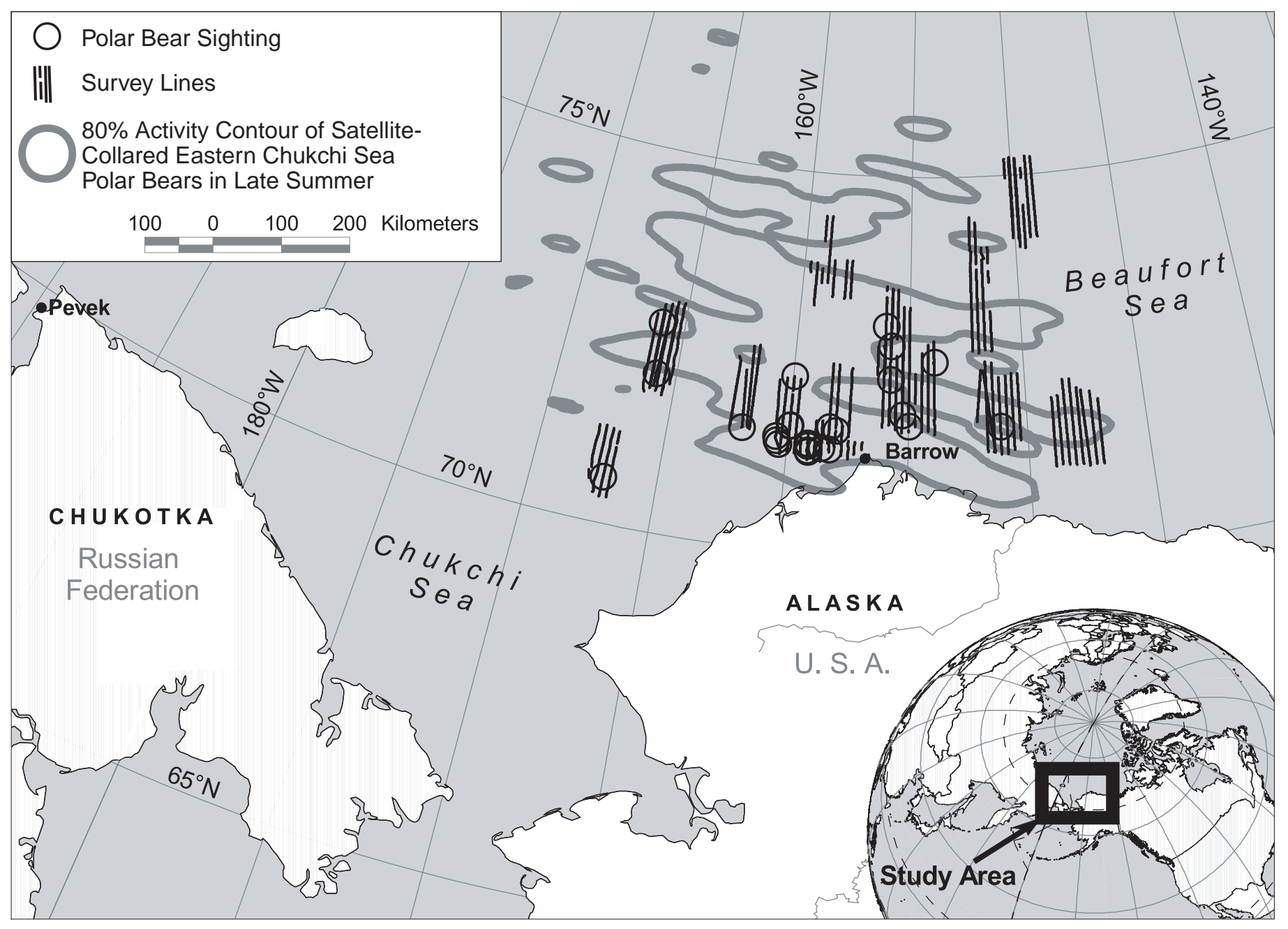

FIG. 1. Study area, flight lines, and polar bear observations in the eastern Chukchi Sea and western Beaufort Sea off northern Alaska during August 2000. Survey efforts focused on the eastern Chukchi Sea study area delineated by the $80 \%$ activity contour of satellite-collared polar bears (Amstrup et al., 2001).

transect was determined from the angle to the sighting, the angle to the bottom of the observer's window, and the aircraft altitude at the time of the sighting. We used ArcInfo (ESRI, Redlands, California) to estimate the length of each surveyed transect from the GPS locations for the starting and ending points. Each transect line was considered a sampling unit. If two portions of a transect line were flown on different flights, they were considered independent samples.

To estimate the polar bear density and variance, we analyzed the sighting data with DISTANCE version 3.5 (Thomas et al., 1998), which estimated the effective strip width, and used bootstrapping to estimate the variance associated with the effective strip width and the encounter rate. Density estimates were calculated by modeling the encounter rate and sightability of polar bear groups as a function of distance from the inside sighting line. We modeled the encounter rate with empirical distributions and modeled the sightability using the half-normal and uniform functions adjusted by polynomial and cosine expansions. All models included a sightability correction factor $\left(\mathrm{g}_{0}\right)$. The best models were selected by considering the Akaike Information Criterion (AIC) and the coefficient of variation $(\mathrm{CV})$ of the estimated density (Burnham and Anderson, 1998). The best models were ranked using AIC and Akaike weights, and then a model-averaged estimator was determined (Anderson et al., 2000).

The survey aircraft allowed for only one observer on each side of the aircraft, and thus we could not develop a sightability correction factor based on paired observers. We approximated a sightability correction factor $\left(\mathrm{g}_{0}\right)$ for polar bears on the inside line of the survey transect with data from a 1994 polar bear aerial survey (McDonald et al., 1999), which used helicopters that accommodated two independent observers on each side of the aircraft. We assumed that sightability during the 2000 survey was similar to the sightability from either the front or the back seat of the 1994 survey and that sightability in both surveys was the same on the left and right sides of the aircraft. Although the survey design was similar for both surveys, we also assumed that the $\mathrm{g}_{0}$ was not affected by who the observers were, or by helicopter type, ice conditions, or time of year. Neither the 1994 nor the 2000 aerial survey corrected for bears that were present in the survey 
TABLE 1. Date, locations (decimal degrees), perpendicular distance (m) from the inside visible edge of transect, and size of polar bear groups sighted by the primary observers while on transect during the August 2000 survey.

\begin{tabular}{|c|c|c|c|c|c|}
\hline Sighting & Date & $\begin{array}{l}\text { Latitude } \\
\qquad\left({ }^{\circ} \mathrm{N}\right)\end{array}$ & $\begin{array}{l}\text { Longitude } \\
\left({ }^{\circ} \mathrm{W}\right)\end{array}$ & $\begin{array}{l}\text { Distance } \\
(\mathrm{m})\end{array}$ & $\begin{array}{l}\text { Group } \\
\text { Size }\end{array}$ \\
\hline 1 & 7 Aug & 70.60 & 167.14 & 141 & 1 \\
\hline 2 & $8 \mathrm{Aug}$ & 72.07 & 165.89 & 405 & 1 \\
\hline 3 & $8 \mathrm{Aug}$ & 72.74 & 166.05 & 104 & 1 \\
\hline 4 & $10 \mathrm{Aug}$ & 71.55 & 161.97 & 39 & 1 \\
\hline 5 & $11 \mathrm{Aug}$ & 71.65 & 159.98 & 292 & 1 \\
\hline 6 & $11 \mathrm{Aug}$ & 71.65 & 159.97 & 83 & 2 \\
\hline 7 & $11 \mathrm{Aug}$ & 72.30 & 159.97 & 512 & 1 \\
\hline 8 & $11 \mathrm{Aug}$ & 71.49 & 160.52 & 51 & 1 \\
\hline 9 & $11 \mathrm{Aug}$ & 71.44 & 160.47 & 365 & 1 \\
\hline 10 & $11 \mathrm{Aug}$ & 71.39 & 158.60 & 254 & 1 \\
\hline 11 & $11 \mathrm{Aug}$ & 71.39 & 158.60 & 276 & 1 \\
\hline 12 & $11 \mathrm{Aug}$ & 71.32 & 159.16 & 81 & 1 \\
\hline 13 & $11 \mathrm{Aug}$ & 71.34 & 159.17 & 186 & 1 \\
\hline 14 & $11 \mathrm{Aug}$ & 71.40 & 159.16 & 980 & 1 \\
\hline 15 & $11 \mathrm{Aug}$ & 71.44 & 159.17 & 20 & 2 \\
\hline 16 & $12 \mathrm{Aug}$ & 71.63 & 158.05 & 650 & 1 \\
\hline 17 & 12 Aug & 71.67 & 158.32 & 675 & 1 \\
\hline 18 & $12 \mathrm{Aug}$ & 71.38 & 158.29 & 229 & 2 \\
\hline 19 & 13 Aug & 73.03 & 156.09 & 150 & 1 \\
\hline 20 & $15 \mathrm{Aug}$ & 71.72 & 155.01 & 51 & 1 \\
\hline 21 & 15 Aug & 71.87 & 155.29 & 7 & 1 \\
\hline 22 & $16 \mathrm{Aug}$ & 71.70 & 151.15 & 145 & 1 \\
\hline 23 & $20 \mathrm{Aug}$ & 72.57 & 153.93 & 405 & 2 \\
\hline 24 & $20 \mathrm{Aug}$ & 72.33 & 155.84 & 82 & 1 \\
\hline 25 & $20 \mathrm{Aug}$ & 72.77 & 155.84 & 25 & 1 \\
\hline
\end{tabular}

transects but not available to be seen (e.g., lying down behind an ice ridge); thus, the $\mathrm{g}_{0}$ from the 1994 survey should be considered a minimum sightability correction factor. We fit sightability model 1 from Manly et al. (1996) to the pooled sighting data from the front and rear seats of the 1994 survey. This model assumes that sightability depends on the distance of the polar bear group from the line and is not affected by either the polar bear group size or the seat position of the observer. The probability of detection on the line $\left(\mathrm{g}_{0}\right)$ and the standard error were estimated by maximum likelihood.

To estimate the effort necessary to decrease the coefficient of variation (CV) in future surveys, we used a simple model that relates the $\mathrm{CV}$ of the estimated density to the survey effort (Wade and DeMaster, 1999). This model assumes that the number of sightings is proportional to the survey effort and that the CV of the density estimate is proportional to the square root of the number of sightings. The proportionality constant from the pilot survey is then

$$
\mathrm{p}=\mathrm{n}_{\text {pilot }}\left(\mathrm{CV}_{\text {pilot }}\right)^{2}
$$

where $\mathrm{n}_{\text {pilot }}$ is the number of sightings on the pilot survey, and $\mathrm{CV}_{\text {pilot }}^{\text {pilot }}$ is the estimated CV from the abundance estimate made during the pilot survey. The $\mathrm{CV}$ of density estimates for future surveys is then estimated to be

$$
\mathrm{CV}_{\text {future }}=\left(\mathrm{p} / \mathrm{L}_{\text {future }}\left(\mathrm{n}_{\text {pilot }} / \mathrm{L}_{\text {pilot }}\right)\right)^{1 / 2}
$$

where $\mathrm{L}_{\text {pilot }}$ is the survey effort flown on the pilot survey, and $\mathrm{L}_{\text {future }}$ is the proposed future survey effort.

\section{RESULTS}

Seventy-one hours of survey were flown during 43 flights from 2 to 28 August 2000. We flew $8265 \mathrm{~km}$ of transect lines $(\mathrm{n}=94)$ under good-to-fair sighting conditions (Fig. 1). Twenty-five polar bear groups consisting of 29 individuals were seen on transect by the primary observers (Table 1). We circled each polar bear group for verification, which for two sightings revealed a second polar bear. Although the weather was often foggy, $75 \%$ of the survey effort occurred in good sighting conditions, $17 \%$ in fair sighting conditions, and $8 \%$ in poor sighting conditions. No bear groups were seen in poor conditions, while five were sighted in fair conditions and 20 in good conditions. We combined the survey effort flown under both good and fair conditions, because there was no significant difference in the distribution of distances at which bear groups were sighted (Wilcoxon Two-Sample Test, $\mathrm{S}=56.5, p=0.585$ ) and the encounter rates were similar $(0.00332$ vs. 0.00296 bear groups $/ \mathrm{km}$ ) under both conditions.

Ice conditions were variable during the survey (Fig. 2). As we flew north, we expected to encounter areas covered with $100 \%$ pack ice. However, we encountered openwater areas even at the northernmost extent of our survey $\left(75^{\circ} 30^{\prime} \mathrm{N}\right)$. In general, ice coverage was greater in northern areas than at southern locations. Most of the ice was classified as first-year or multi-year ice. The most commonly encountered ice forms were pancake ice, cake ice, and small to medium floes. Big floes were not encountered frequently except north of $75^{\circ} \mathrm{N}$. In general, the ice was unconsolidated and moving with evidence of both thawing and freezing. Polar bears were sighted in a broad range of ice cover (Fig. 2). Although $9.3 \%$ of our survey effort occurred in areas with less than $10 \%$ ice cover and $2.7 \%$ in areas with $100 \%$ ice cover, no bears were seen under either of these conditions. The greatest concentration of bears seen $(16 / 25)$ occurred in an area along the southern edge of the ice, approximately 96 to $160 \mathrm{~km}$ northwest of Barrow (Fig. 1).

Satellite telemetry data from radio-collared female polar bears have indicated that polar bears have a tendency to congregate along the ice edge during the fall when the ice begins to form and move south (Garner et al., 1992). The August 2000 survey was conducted before a well-defined ice edge had formed (which normally occurs in October). Although evidence of polar bear activity was seen in all areas, the majority of the polar bear sightings occurred within the southern portion of the study area, where the ice was less consolidated and seal and walrus sightings were more common.

Polar bears feed primarily on ringed seals (Phoca hispida) and to a lesser degree on bearded seals (Erignathus barbatus) and spotted seals (Phoca largha). The sightings 


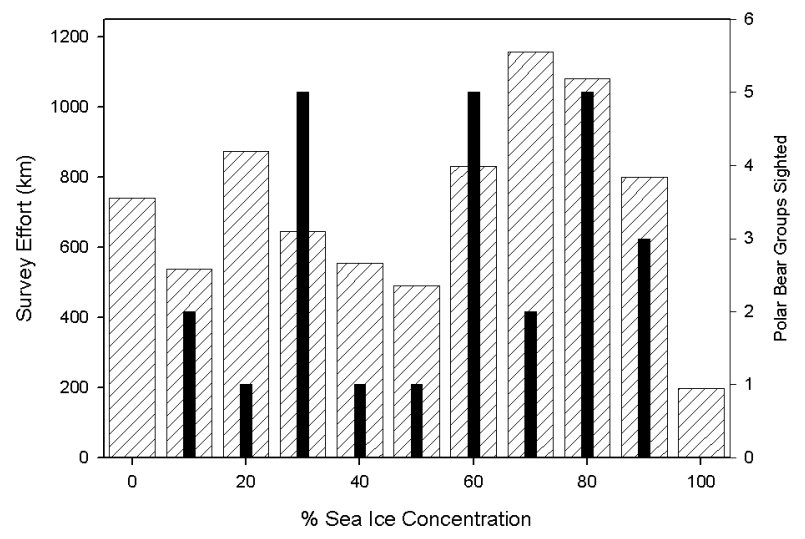

FIG. 2. Polar bear sightings relative to sea ice concentrations encountered during the aerial survey for polar bears in the eastern Chukchi and western Beaufort Sea in August 2000. Hatched bars represent the transect distance flown over each sea ice concentration. Thin black bars represent the number of polar bears sighted over each sea ice concentration.

of polar bears and their primary prey substantiate the association of polar bear distribution with prey distribution. More bear groups were sighted on flights that included sightings of polar bear prey (16 polar bear groups on $2511 \mathrm{~km}$ of transect) than on flights that did not include the sighting of prey ( 9 polar bear groups on $5754 \mathrm{~km}$ of transect, $\chi^{2}=13.36$, d.f. $\left.=1, p<0.001\right)$.

The probability of detecting bears decreased with increasing perpendicular distance from the inside edge of the survey strips (Fig. 3). A comparison of the detection models is presented in Tables 2 and 3. The small differences between the AIC values made it difficult to justify a choice of best model. Consequently, we chose model averaging to develop a density estimate that will have reduced bias when compared to a single density estimate from any one model (Anderson et al., 2000).

We estimated the density of polar bear groups by dividing the number of bears encountered ( 25 bear groups) by the effective area surveyed $(8265 \mathrm{~km}$ survey transect length $\times 0.441 \mathrm{~km}$ effective survey strip width). The group density estimate was adjusted by $\mathrm{g}_{0}$, which was calculated to be 0.667 ( $\mathrm{SE}=0.144)$. The DISTANCE 3.5 program extrapolated the density of individual bears using the mean observed group sizes $(1.16 \pm 0.075 \mathrm{SE})$. We estimated a density of 0.0068 bears per $\mathrm{km}^{2}$, with upper and lower $95 \%$ confidence bounds of 0.032 and 0.014 , respectively. This translates to an average of one bear per $147 \mathrm{~km}^{2}$ (95\% confidence limits 71 to 313 ). If we consider only survey effort that was flown over areas of $10 \%$ or greater ice coverage $(7525 \mathrm{~km})$, the estimate of polar bear density was 0.0075 ( $95 \%$ confidence limits 0.0057 to 0.025 ), or $133 \mathrm{~km}^{2}$ per bear (95\% confidence limits 40 to 175 ).

Standard outputs from the DISTANCE 3.5 program allowed us to examine sources of variation in the density estimate. Since it was not possible to make this determination for the averaged model, we examined the sources of variation for the half-normal model, which had the lowest CV (37\%). The encounter rate was the greatest source of

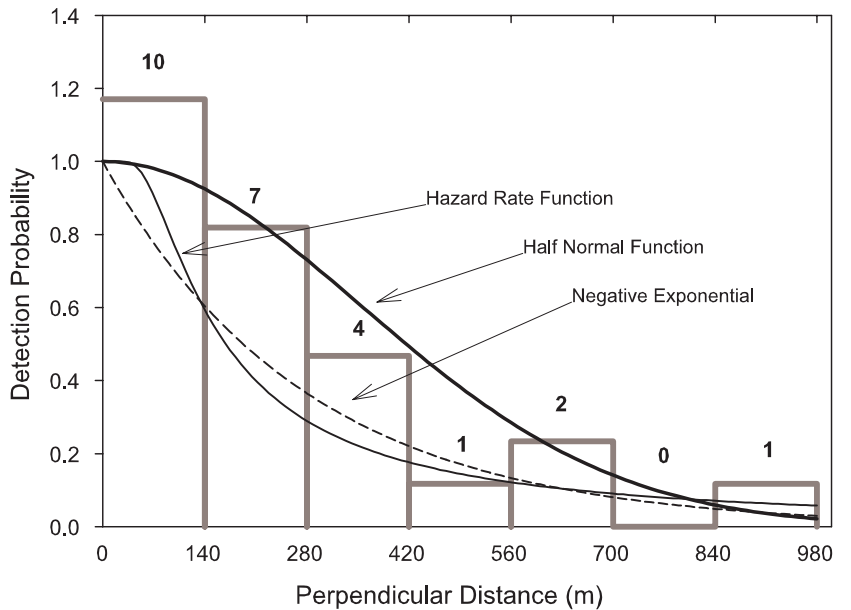

FIG. 3. Histogram of perpendicular sighting distances and modeled probability detection functions for polar bear groups sighted during the August 2000 aerial survey. The value above each histogram bar represents the number of polar bear groups sighted in that distance interval.

variance $(53.2 \%)$. This variance may be due to variability in sighting conditions or inherent to the sampling of animals at low densities. The estimate of $g_{0}$ was the next greatest source of variance (34.9\%), followed by the distance detection function $(9.5 \%)$ and polar bear group size (3.1\%). The predicted CV for future surveys is plotted as a function of survey effort in Figure 4. Doubling the survey effort to about $18600 \mathrm{~km}$ would reduce the $\mathrm{CV}$ of the density estimate from $38 \%$ to $26 \%$. Another way to reduce the $\mathrm{CV}$ would be to stratify future survey efforts into areas of high and low polar bear density based on ice habitat conditions. The CV values were lower for the line-transect models, which excluded areas with less than $10 \%$ ice (Table 3).

\section{DISCUSSION}

Most polar bear abundance estimates have come from mark-recapture methods, which require large sample sizes, well-defined population bounds, and low variance with respect to capture probabilities to obtain robust and unbiased estimates. Although mark-recapture methods have been used to estimate the population in the Southern Beaufort Sea off northern Alaska (Amstrup, 1995; Amstrup et al., 2001), logistical constraints (such as variable ice conditions, extreme weather, limited range of helicopters, and extremely large polar bear home ranges) have precluded efforts to apply mark-recapture methods in the Chukchi Sea. Line-transect methodology is currently the best method available to assess population densities for remote populations where mark-recapture studies are not practical (Wiig and Derocher, 1999). The results from our study in the eastern Chukchi Sea and western Beaufort Sea may provide a framework from which to develop a more extensive survey for the entire Chukchi/Bering Seas population.

We sought to estimate the density and size of the eastern Chukchi Sea polar bear population. The boundaries of the 
TABLE 2. Comparison of line-transect models for the entire study area in the eastern Chukchi Sea and western Beaufort Sea in August 2000. The sampling unit was a flight along a randomly selected transect. Only polar bears seen by primary observers while on transect flights with good or fair visibility $(8265 \mathrm{~km})$ were used in the analysis $(25$ polar bear groups consisting of 29 animals $)$. AIC = Akaike Information Criterion, $\mathrm{CV}=$ Coefficient of Variation, $\mathrm{LCL}=95 \%$ Lower Confidence Limit, UCL $=95 \%$ Upper Confidence Limit, $\mathrm{w}=\mathrm{Akaike}$ weights.

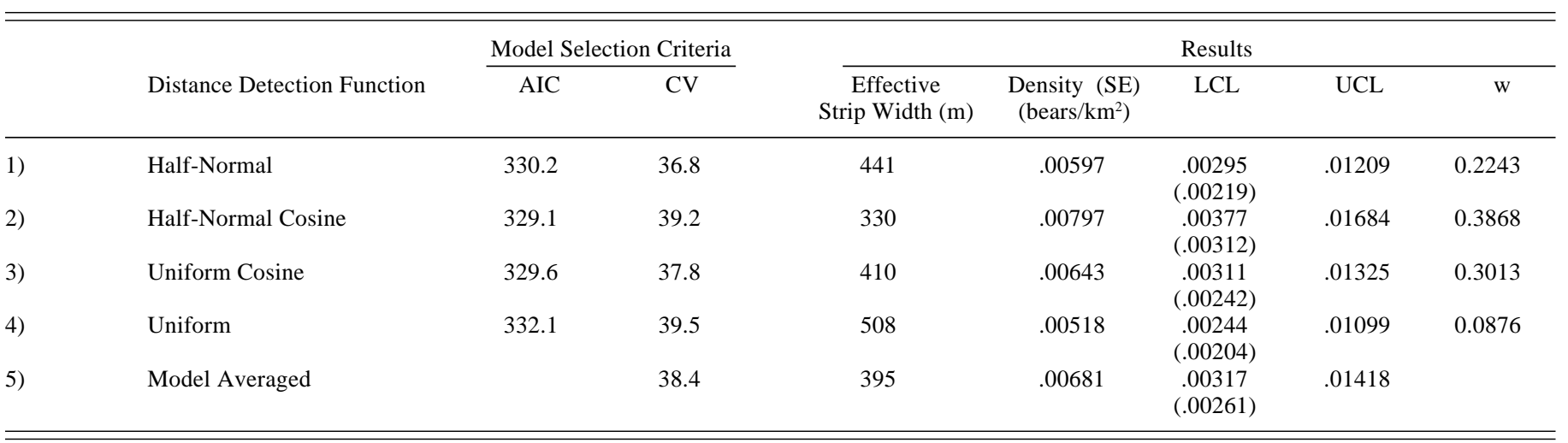

TABLE 3. Comparison of line-transect models for areas with greater than $10 \%$ ice concentration in the eastern Chukchi Sea and western Beaufort Sea in August 2000. The sampling unit was a flight along a randomly selected transect. Only polar bears seen by primary observers while on transect flights with good or fair visibility $(7526 \mathrm{~km})$ were included in the analysis (25 polar bear groups consisting of 29 animals). AIC = Akaike Information Criterion, CV $=$ Coefficient of Variation, LCL $=95 \%$ Lower Confidence Limit, UCL $=95 \%$ Upper Confidence Limit, $\mathrm{w}=$ Akaike weights.

\begin{tabular}{|c|c|c|c|c|c|c|c|c|}
\hline & \multirow[b]{2}{*}{ Distance Detection Function } & \multicolumn{2}{|c|}{ Model Selection Criteria } & \multicolumn{5}{|c|}{ Results } \\
\hline & & AIC & $\mathrm{CV}$ & $\begin{array}{c}\text { Effective } \\
\text { Strip Width (m) }\end{array}$ & $\begin{array}{l}\text { Density (SE) } \\
\left(\text { bears } / \mathrm{km}^{2} \text { ) }\right.\end{array}$ & LCL & UCL & $\mathrm{w}$ \\
\hline 1) & Half-Normal & 330.2 & 36.6 & 441 & .00655 & $\begin{array}{c}.00325 \\
(.00239)\end{array}$ & .01321 & 0.2242 \\
\hline 2) & Half-Normal Cosine & 329.1 & 38.8 & 330 & .00875 & $\begin{array}{l}.00416 \\
(.00341)\end{array}$ & .01840 & 0.3868 \\
\hline 3) & Uniform Cosine & 329.6 & 37.4 & 410 & .00705 & $\begin{array}{c}.00344 \\
(.00264)\end{array}$ & .01447 & 0.3013 \\
\hline 4) & Uniform & 332.1 & 39.1 & 508 & .00568 & $\begin{array}{c}.00269 \\
(.00223)\end{array}$ & .01202 & 0.08762 \\
\hline 5) & Model Averaged & & 38.6 & 395 & .00748 & $\begin{array}{c}.00568 \\
(.00288)\end{array}$ & .02498 & \\
\hline
\end{tabular}

study area were based on telemetry data from 36 radiocollared adult female polar bears, whose movements indicated fidelity to an area distinct from that occupied by other groups of satellite radio-collared polar bears to the east in the southern Beaufort Sea and to the west in the Chukchi and Bering Seas (Amstrup et al., 2001). Although the survey was designed to cover the entire study area, our survey effort was not uniformly distributed. Given time and logistical constraints, we were able to obtain adequate coverage from east to west only in the southern portion of the study area. Only a small portion of the survey effort occurred in the north, and no surveys were conducted in the northwest corner. The maps of the sea ice extent from the National Oceanic and Atmospheric Administration and National Snow and Ice Data Center did not accurately describe the variable ice conditions encountered in August 2000 , and the spatial and temporal resolutions were not sufficient to compare ice habitat conditions between the survey areas and those not surveyed. Since we had no means to determine whether the sea ice habitat was similar in the two areas, our results were not applied to the entire

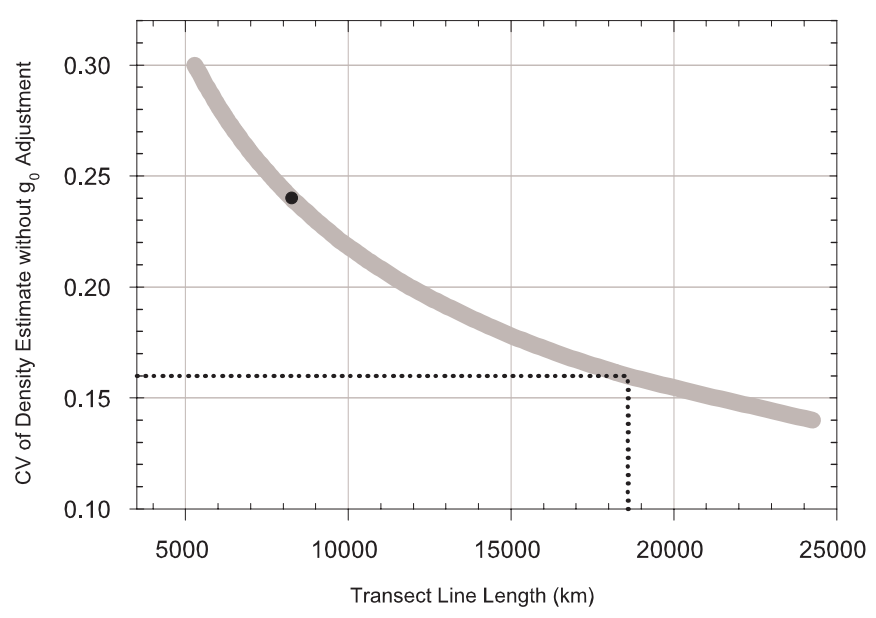

FIG. 4. Predicted CV of estimated density relative to survey effort $(\mathrm{km})$ based on a model described by Wade and DeMaster (1999) and our survey results. The grey line represents the power analysis curve. The black dot represents the August 2000 survey effort $(8265 \mathrm{~km})$, and the solid line represents the results based on 25 sightings in August 2000. The lower dotted line represents the density $\mathrm{CV}$ if the survey effort were doubled. 
TABLE 4. Polar bear density estimates from aerial surveys conducted in the Chukchi and Beaufort Seas.

\begin{tabular}{|c|c|c|c|c|c|c|}
\hline Location & Date & $\begin{array}{l}\text { Number of } \\
\text { Bear Groups }\end{array}$ & $\begin{array}{r}\text { Bear Density } \\
\left(\text { bears } / \mathrm{km}^{2}\right)\end{array}$ & $\mathrm{Km}^{2} /$ bear & $\mathrm{CV}$ & Source \\
\hline $\begin{array}{l}\text { Eastern Chukchi Sea } \\
\text { Western Beaufort Sea }\end{array}$ & $8 / 2000$ & 25 & 0.00681 & 147 & 0.38 & This study - Averaged Model \\
\hline Beaufort Sea & $6 / 1994$ & 15 & 0.00352 & 284 & 0.73 & McDonald et al., 1999 \\
\hline $\begin{array}{l}\text { Chukchi Sea } \\
\text { Beaufort Sea } \\
\text { Kotzebue to Kaktovik }\end{array}$ & $4 / 1987$ & 12 & 0.00224 & 446 & 0.51 & McDonald et al., 1999 \\
\hline $\begin{array}{l}\text { Chukchi Sea } \\
\text { Kotzebue }\end{array}$ & $4 / 1987$ & 1 & 0.00108 & 926 & 1.03 & McDonald et al., 1999 \\
\hline $\begin{array}{l}\text { Chukchi Sea } \\
\text { Lisburne }\end{array}$ & $4 / 1987$ & 4 & 0.00309 & 324 & 0.61 & McDonald et al., 1999 \\
\hline $\begin{array}{l}\text { Western Beaufort Sea } \\
\text { Eastern Chukchi Sea } \\
\text { Barrow }\end{array}$ & $4 / 1987$ & 1 & 0.00061 & 1640 & 1.05 & McDonald et al., 1999 \\
\hline
\end{tabular}

survey area. In addition, the lower density of bears encountered in areas with $100 \%$ ice cover violated the assumption of uniform bear distribution; thus, our density estimates were not extrapolated to areas not surveyed. Although we were unable to estimate the abundance of the polar bear population, we were still able to calculate a density estimate for the area surveyed.

Our estimate of polar bear density was greater than previous survey estimates (Table 4). Differences between density estimates may be due to one or more of the following: (1) differences in the survey areas, (2) differences in the timing, (3) differences in survey methods, observers, and survey effort, (4) differences in the distribution of ice habitat or polar bears or both, (5) an increase in the number of polar bears, or (6) the accuracy of this and previous surveys (McDonald et al., 1999). Compared to previous efforts, our survey had the lowest CV and the greatest number of sightings (Table 4). The survey conducted out of Barrow in April 1987 is most comparable to ours for area surveyed. Since the aerial surveys occurred in different areas and at different times of the year, it was impossible to compare their results directly. Also our use of a sightability correction factor from a previous survey most likely resulted in biased density estimates (e.g., using an estimated $\mathrm{g}_{0}$ that is higher than reality will overestimate the true density). This problem indicates the importance of developing a sightability correction factor for each survey. The $\mathrm{CV}$ for this survey from the averaged model was 38\%, which means that if we could repeat the survey with the same precision, in the same area, and under the same ice and weather conditions, we would expect to be able to detect a $76 \%$ change in density with about $95 \%$ confidence.

The greatest source of variation was the encounter rate. Using the predictive model that compares the CV of the estimated density to survey effort (Wade and DeMaster, 1999), the precision of the aerial survey could be increased by $12 \%$ if the survey effort were doubled. To accomplish this, we would need to add a second icebreaker or conduct the survey for a longer period. It is hoped that surveying later in the year, to coincide with the formation of a well- defined ice edge and the advance of the pack ice, would increase the number of bear sightings and the encounter rate and lower the $\mathrm{CV}$. The second greatest source of variation was the sightability correction (35\%). To reduce this source of variation, we would need to increase the double observer effort conducted in the earlier surveys with two observers on the same side of the aircraft. However, this was not an option in August 2000, given the constraints on use of the USCG helicopters.

Polar bear distribution is strongly tied to sea ice dynamics (Garner et al., 1990; Amstrup, 1995; Amstrup et al., 2000). Although polar bears in the Chukchi and southern Beaufort Seas generally move with the pack ice as it advances in winter and recedes in summer, the specific factors that determine their distribution and movement on the ice are not completely understood. Wind, currents, and seasonal changes in the weather affect the movement, location, and types of ice encountered and, to some extent, the location and availability of prey. In addition, seasonal human activities near shore or on land may also affect polar bear distribution (Amstrup, 1995). Since we have no way of factoring out all these variables, direct statistical comparisons between the survey results were not justified; thus, the comparisons in Table 4 are useful for illustrative purposes only.

The primary goal of this survey was to assess the logistical support facilities available on the USCG icebreakers and survey methods for polar bear population assessment. If a survey-specific sightability correction could be developed, then a comprehensive population survey for the Chukchi/Bering Seas population would be possible using a USCG icebreaker with helicopter support. In the Chukchi Sea, ship-based aerial surveys are superior to land-based aerial surveys, which may be severely hampered by variable ice conditions. Land-based aerial surveys sometimes require travel over long distances to reach the ice, whereas ship-based aerial surveys may be launched from the ice edge or from points many kilometers within the ice pack. In addition, severe weather forces land-based aircraft to retreat earlier than ship-based aircraft when 
they must return to safety. The USCG Ship of Opportunity was cost-effective in allowing us to test ship-based aerial survey methods. However, to accomplish an adequate survey of the study area or of the entire Chukchi Sea, we would need dedicated ship time to select the time of year and route of the icebreaker. Dedicated ship time would substantially increase survey costs. We believe that the best time to conduct a population-wide survey is late fall, when the ice edge is better defined and bears congregate at the edge of the pack ice and newly forming ice (Garner et al., 1992).

\section{ACKNOWLEDGEMENTS}

We would like to thank the personnel of the USCG icebreaker Polar Star for providing the ship and accommodations during the aerial survey. Captain T. Julius was instrumental in providing leadership and coordinating the ship's activities with the scientific program objectives. We would like to thank the entire aviation crew for conducting surveys in a professional and safe manner. Funding was provided by the U.S. Coast Guard under the Ship of Opportunity Program and by the U.S. Fish and Wildlife Service. Douglas Burn, Paul Flint, Jeff Laake, Lyman McDonald, and Trent McDonald provided helpful suggestions and comments on the survey design and earlier drafts of this manuscript. We thank A.E. Derocher and two anonymous reviewers for constructive criticism of the manuscript.

\section{REFERENCES}

AMSTRUP, S.C. 1995. Movements, distribution, and population dynamics of polar bears in the Beaufort Sea. PhD Thesis, University of Alaska-Fairbanks, Fairbanks, Alaska. 299 p.

AMSTRUP, S.C., DURNER, G.M., STIRLING, I., LUNN, N.J., and MESSIER, F. 2000. Movements and distribution of polar bears in the Beaufort Sea. Canadian Journal of Zoology 78(6):948-966.

AMSTRUP, S.C., McDONALD, T.L., and STIRLING, I. 2001. Polar bears in the Beaufort Sea: A 30-year mark-recapture case history. Journal of Agricultural, Biological, and Environmental Statistics 6(2):221-234.

ANDERSON, D.R., BURNHAM, K.P., and THOMPSON, W.L. 2000. Null hypothesis testing: Problems, prevalence, and an alternative. Journal of Wildlife Management 64(4):912-923.

BURNHAM, K.P., and ANDERSON, D.R. 1998. Model selection and inference: A practical information-theoretic approach. New York: Springer Verlag. 353 p.

GARNER, G.W., KNICK, S.T., and DOUGLAS, D. 1990. Seasonal movements of adult female polar bears in the Bering and
Chukchi Seas. International Conference of Bear Research and Management 8:219-226.

GARNER, G.W., McDONALD, L.L., ROBSON, D.S., YOUNG, D.P., and ARTHUR, S.M. 1992. Literature review: Population estimation methodologies applicable to the estimation of abundance of polar bears. Technical Report dated 30 September 1992. Anchorage, Alaska: U.S. Fish and Wildlife Service, Alaska Fish and Wildlife Research Center. 102 p.

LUNN, N., SCHLIEBE, S., and BORN, E., eds. 2002. Polar bears: Proceedings of the 13th Working Meeting of the IUCN/SSC Polar Bear Specialist Group, Nuuk, Greenland. Gland, Switzerland and Cambridge, United Kingdom: IUCN. vii + $153 \mathrm{p}$.

MANLY, B.F.J., McDONALD, L.L., and GARNER, G.W. 1996. Maximum likelihood estimation for the double-count method with independent observers. Journal of Agricultural, Biological, and Environmental Statistics 1(2):170-189.

McDONALD, L.L, GARNER, G.W., and ROBERTSON, D.G. 1999. Comparison of aerial survey procedures for estimating polar bears density: Results of pilot studies in northern Alaska. In: Garner, G.W., Amstrup, S.C., Laake, J.L., Manly, B.F.J., McDonald, L.L., and Robertson, D.G., eds. Marine mammal survey and assessment methods. Rotterdam: A.A. Balkema. $37-51$.

OVSYANIKOV, N. 2003. Dark times for Chukotka polar bears. WWF Arctic Bulletin 2.03:13-14.

SMITH, O.P. 2000. Observers' guide to sea ice. National Oceanic and Atmospheric Administration, Hazardous Materials Response Division, Office of Response and Restoration. 27 p.

THOMAS, L., LAAKE, J.L., DERRY, J.F., BUCKLAND, S.T., BORCHERS, D.L., ANDERSON, D.R., BURNHAM, K.P., STRINDBERG, S., HEDLEY, S.L., BURT, M.L., MARQUES, F.F.C., POLLARD, J.H., and FEWSTER, R.M. 1998. DISTANCE 3.5. St. Andrews, United Kingdom: Research Unit for Wildlife Population Assessment, University of St. Andrews.

U.S. FISH AND WILDLIFE SERVICE. 2002a. Polar bear (Ursus maritimus): Chukchi/Bering Seas stock. Marine Mammal Protection Act Stock Assessment Report. 6 p.

— 2002b. Polar bear (Ursus maritimus): Southern Beaufort Sea stock. Marine Mammal Protection Act Stock Assessment Report. 5 p.

WADE, P.R., and DeMASTER, D.P. 1999. Determining the optimum interval for abundance surveys. In: Garner, G.W., Amstrup, S.C., Laake, J.L., Manly, B.F.J., McDonald, L.L., and Robertson, D.G., eds. Marine mammal survey and assessment methods. Rotterdam: A.A. Balkema. 53-66.

WIIG, Ø., and DEROCHER, A.E. 1999. Application of aerial survey methods to polar bears in the Barents Sea. In: Garner, G.W., Amstrup, S.C., Laake, J.L., Manly, B.F.J., McDonald, L.L., and Robertson, D.G., eds. Marine mammal survey and assessment methods. Rotterdam: A.A. Balkema. 27-36. 